\title{
CHILD LITERATURE GENRE FORMULATION IN WALT DISNEY ANIMATION MOVIE
}

\author{
Lisma Linda ${ }^{1}$. Universitas iskandarmuda, Banda Aceh \\ $\underline{\text { lisma.linda90@gmail.com }}$ \\ Tomi Arianto². Universitas Putera Batam, Batam- Kepri \\ tomy2088.ta@gmail.com
}

\begin{abstract}
Asbtrak
Penelitian ini mengkaji tentang formulasi pada child literature genre dengan sumber data berupa Walt Disney Animation Movie sellection. Tangled (2010), Brave (2012) and Frozen (2013) merupakan 3 movie Walt Disney yang dipilih sebagai data dalam penelitian ini. Pendekatan yang digunakan oleh peneliti dalam kajian ini berupa pendekatan sastra popular pada genre sastra anak berdasarkan teori Cawelty dan teori pendukung lainnya. Sastra anak pada umumnya merupakan sebuah karya yang diciptakan untu kanak-anak yang mana bahasa dan ceritanya lebih sederhana dan mudah dipahami dengan tujuan untuk menghibur dan mendidik anak-anak pada usianya; membantu anak dalam mengembangkan imajinasi, mampu memahami arti kehidupan, mampu membedakan karakter manusia dan lain sebagainya. Namun lebih dari itu Sastra anak juga menampilkan sesuatu yang unrealistic tetapi dapat diterima oleh anak tersebuts ebagai sesuatu yang wajar dan masuk akal dalam sebuah film. Hal ini disebabkan oleh kecerdasan produsen dalam menentukan arah produksinya sehingga masyarakat benar-benar merasa dipuaskan. Dalam kajian inilah peneliti menemukan bahwa meskipun alur plot dalam karya popular disajikan dengan berbagai macam inovasi dan kreatifitas produser, namun ada formula yang menjadi konvensi sehingga sastra anak dapat diterima sebagai kewajaran sehingga mengaburkan batasan realitas dan unrealitas dalam karya sastra.
\end{abstract}

Kata Kunci: Sastra anak, Walt Disney, Formula, dan Sastra Populer

\section{INTRODUCTION}

Children's literature is a work created for children where language and story are simpler and easier to understand with the aim of entertaining and educating children at their age. The purpose of children's literature work was usually to help children develop imagination, be able to understand the meaning of life, and be able to distinguish human characters. As the development of the age, child literature and adult literature were very difficult to distinguish. For example, the Harry Potter story which was originally created specifically for children but ultimately also demanded by adults. Huck's (2010) said in his book that children read books written for adults, trying to understand what is in them. J.K
Rowling's work was claimed to be created for adults, but in fact it was a story created for children.

Children's literature and adult literature have different characters. Child literature tended to tell about the lives of children who often didn't make sense. For example, Doraemon cartoon characters that can fly with bamboo propellers or can help Nobita with various kinds of tools stored in her magic bag. In fact, Doraemon bags that have a small size were unlikely to accommodate so many tools that were needed, such as doors anywhere, and planes for space spaces. However, there was a convention that makes the audience feel that this was a natural and reasonable thing in a movie. 
Walt Disney production was one of the big companies producing children's movies such as Cinderella Story, Toys Story, Tinker Bell, Alice in Wonderland. Movies produced by Walt Disney can always steal the attention of people around the world, even movies created for children are also enjoyed by teenagers and adults such as Tangled (2010), Brave (2012) and Frozen (2013).

Popular literature or popular literature was a work that prioritizes the pleasure of readers or usually presented in simple forms that were easy to understand so that readers could enjoy it. Popular literature was produced based on experience and lifts stories from everyday people's lives, then packaged in such a way as to attract the attention of the audience. Many people who disagree with translation popular literature as popular literature because in the Indonesian context literature was a noble writing caused by different connotations (Adi Rochani, 2011).

Although initially popular literature was considered low and not qualified, it was undeniable that popular literature enthusiasts increasingly increased with the times. People no longer wanted to think hard with words that were difficult to understand. They tended to choose readings that were easy to understand and interesting to enjoy everyday. Tangled, Brave and Frozen are categorized as kinds of popular literature. The results of the www.imdb.com were Tangled survey obtained a 7.9 rating, Brave got a 7.2 rating and Frozen got a rating of 7.8 .

The research that rose about the study of popular literature was carried out by several previous researchers. First, research that also used the Cawelty theory was carried out by Mulhern (1999) in his journal entitled Japanese Harlequin Romances as Transcultural Woman's Fiction. Mulhern attributed the feminist approach to the
Japanese romance in the Harlequin series and linked it to the Cawelty theory. From the formula of the Harlequin romance story, He raised the critical issue of Japanese women which is now wholly given to the mob of scribbling women, "goes one of the most frequently quoted genderrelated adages".

The second study was written by Swirski (1999) In his journal, "Popular and Highbrow Literature: A Comparative View,". Swirski discussed the role and status of popular fiction in contemporary culture. Starting with the basic question, "Who needs popular fiction?," he surveys select sociological evidence and prevailing aesthetic arguments in order to take stock of the ways in which highbrow literature and popular fiction relate to each other. He begins with statistical and socio-economic data which casts a different lights on many myths prevailing in scholarship as well as in general social and cultural discourse, such as the death of the novel, the alleged decline of the reading public, and the role of paperback publishing and commercial pressures in shaping literary production. In the second part of the article Swirski examined the most persistent aesthetic arguments used to deride and attack popular literature. Both parts of the article are, in fact, extended arguments for a greater literary democracy, reflected in his recommendations for a critical response to popular fiction more compatible with its actual socio-aesthetic status.

At the national level there are also studies that use the theory of formulas, one of which is carried out by Adi (2014) with the title Serial Television Dexter as Anachronism in Popular Literature. Adi's research aimed to investigate: (1) how the formulation of the characterization of Dexter in the television serial 
Dexter violates the tradition of literary characterization, and (2) how the formula of moral values is dramatized through Dexter, who is a sociopath, psychopath, serial killer, and person without moral. The

research object was the television serial Dexter, which ranks five in popularity in the world. The data were collected by documenting 84 episodes of the serial having been broadcast since 2006. Based on the findings, the conclusions are as follows. First, there is a violation or anachronism of characterization through the main character in the serial. Second, the dramatized moral values still contain conventional values although they are in different forms.

The three studies above are of course different from the research that the researchers did in this paper. The data source used by researchers is popular literature in the children's literature genre. To the knowledge of the researchers, research on popular literature especially in the three selected data sources no one has done. The researcher wants to see a comparison of the formulas found in Tangled (2010), Brave (2012) and Frozen (2013) movies using Cawelty theory. This research is expected to become a new dimension and reference for the study of literature with contemporary approaches such as the application of Cawelty theory applications.

\section{Frozen Movie Synopsis}

The movie titled "Frozen" was one of the movies produced by Walt Disney in 2013. The movie told the story of a princess named Anna (Kristen Bell) and her friends against Snow Queen (IdinaMenzel) which freezes the entire kingdom. Snow Queen was none other than Anna's sister, her name was Elsa.
One day, Anna and Elsa play snowballs at the palace, Arendelle. They made snow assisted by magic owned by Elsa, but Elsa accidentally hurt Anna with her magic so that Anna's hair turned white and must be healed by the love fairy. The two of them were separated by kings and queens until Elsa could control her magic. Once, the queen and the king went sailing and a storm hit them and they died. Futhermore, Elsa was appointed as a queen. On the day of the coronation, it was the first time the palace door was opened again and Anna met a man who claimed to be a prince named Hans. In a short time they immediately expressed love and wanted to get married, but Elsa forbade the reason they had only known for one day. Anna disagreed with Elsa's decision and asked for an in-depth explanation, so Elsa was angry and could not control her magic, she almost harmed Anna again. Elsa was really scared because the magic was already known by many people and there were those who shouted at her a monster. He ran away from the palace to isolate himself.

Because of this incident, Anna was very sorry and felt guilty. He left the palace to look for Elsa and leave the palace to Hans. In Elsa's search, he met a man named Kristoff (Jonathan Groff) and a snowman created by Elsa named Olaf (Josh Gad). Full of struggle they sought the queen and took her home, but Elsa refused. Because Anna forced again, Elsa released her strength again, accidentally hurt Anna. Anna's hair turned white and she was taken to the place of the fairy of love, this time she couldn't be saved except with true love. They returned to the palace to meet Hans, but what happened was Hans was not Anna's parallel love but a dirty human who was so thirsty for power. He locked Anna and told everyone that Anna had died. 
Elsa finally captured by Hans, but in Elsa's palace he resisted and his strength grew stronger until a snowstorm occurred. Kristof who watched the storm from a distance immediately returned to the palace to save Anna. When Elsa fought back, Hans almost killed him with a sword but Anna held him back and suddenly he froze to ice. Elsa was very sorry because her sister was willing to save her, she hugged Anna's statue while crying. But suddenly Anna's body turned normal and she recovered from her brother's true love. They also live happily.

\section{Tangled Movie Synopsis}

Tangled was also a movie produced by Walt Disney Picture. This movie tells the story of a princess named Rapunzel who has beautiful hair. When pregnant, the queen was seriously ill and the king asked the troops to find a magical flower in the forest. The troops came home with the flowers; the queen could be healed again and gave birth to the Rapunzel with beautiful hair.

One day a magician named Gothel came to kidnap Rapunzel, this was because Rapunzel's hair had the power of a magical flower which the flowers used to heal the queen were usually used by Gothel in his treatment to stay young all his life. Dozens of years Rapunzel lives with a witch whom she calls mother. He was not allowed to come out on the grounds that the outside world was too cruel. One day, a thief named Flynn accidentally entered his residence. With the presence of the man, his life has changed. He had dared to leave home and go on an adventure with Flynn, until finally Rapunzel met his parents again.

\section{SinopsisMovie Brave}

The movie tells about a royal princess named Merrida who is proficient in archery.
Merrida is a person who is brave, ignorant, aggressive and intelligent. King Fergus, AyandaMerrida, presented him with an arrow when he was a birthday, precisely when he was a child. It's different with RatuElinor, Meriida's mother, wanting her child to be a perfect princess in the eyes of another prince until she always forced Merrida to obey the royal rules that made Merrida suddenly crazy.

One day Merrida was introduced to three princes and the one who could win the archery race would be his soul mate. It turned out that Lord Dingwall's son had accidentally won the match, but Merrida refused until the queen became angry and wrapped her bow. Out of anger, she left home until she found a light which was her conscience. She arrived at a house where the occupant was a magician. She asked the magician for a spell to change her mother so as not to force her own will. Her mother was hit with magic and became a bear, but Merrida forgot her spell so she could not return her mother.

Because of her carelessness, Merrida was forced to protect and protect her mother from the king who did not believe that the bear was her wife. Merrida's relationship and queen are getting closer. She spent her days with the queen outside the palace. Until one day the king found them and wanted to kill the bear, but Merrida deflected her and accidentally a painting of their family that had been torn and sewn by a queen hit her body, she again turned into a human.

\section{THEORY OF THE RESEARCH}

The approach used in this paper is formula analysis. In determining a formula, of course researchers must know about the genre first because they are interrelated. Adi (2011) in her book said that in general the understanding of genre is type or grouping. Similarly, Nurgiyantoro 
(2004) in his journal said that genre can be understood as a type or type of literacy that has a set of general characteristics, or categories of grouping of literary works that are usually based on stlye, shape, and content. From the two meanings above it can be concluded that genre is a grouping of characteristics or types based on several factors, namely style, shape, content, theme, structure, language and so on. In popular literature consists of several genres, including: action, adventure, animation, children literature, family, comedy, drama, and so on. Wellek and warren in Adi said:

In our opinion, the genre is a grouping of literary works that are theoretically based on external forms (majas or special structures) and internal forms (attitudes, tones, goals, subjects, and audiences) The basis of which appears (for example, 'pastoral' and 'satire' "for forms in poetry dipodic and pincaric for external forms), but the problem then is to look for another dimension, to complete the diagram)" (Adi Rochani, 2011).

With the development of technology in this era of globalization, the influence of popular literature is so rapid that the number of genres can increase at any time according to the interest of the audience. According to Adi (2011), determining the genre of popular fiction depends on the audience and the audience, which is the indicator of whether or not the fiction is sold. Producers will not publish it if it is considered inappropriate and does not sell. Determining the genre can be based on several factors such as themes, characters, settings, and story lines.

Formulas are elements of literary works that cannot be separated by genre. Cawelty (1976) said that the literary formula is basically a narrative or drama convention that is widely applied in each individual author's work. Thus, if researching genres means researchers also research formulas. Tolson in Adi (2011) said that genre is a category that connects industry and its audience. In this case the audience can never be separated from the formula research because the producer creates a formula also based on the expectations and requests of the audience.

\section{METHOD OF RESEARCH}

This research is a qualitative research. The method that is used in this study is library research and close reading. Qualitative research is best suited for literary phenomena because literature is a world of words and symbols that are full of meaning. Endraswara (2011) in her book said that literature is not a phenomenon that easily calculated like the phenomenon of natural science. An important feature of qualitative research in literary studies according to Endraswara (2011) stated that: 1) researchers are a key instrument will read carefully a literary work, 2) research done on a regular basis descriptive, meaning decomposes in the form of words or images if necessary, not a number, 3) preferring process rather than result, because literary work is a phenomenon that invites many interpretations, 4) inductive analysis, 5) meaning is the mainstay. This research is done through two stages, namely data collection and data analysis. However, before the two stages of the study are described, it is necessary known place of research, population, sample, and data in this research.

\section{DISCUSSION}

Lukens (2013) classifies children's literary genres into six types, namely Realism, formula fiction, fantasy, traditional literature, poetry, and non-fiction. Each group still has another subgroup called sub-genre. Whereas Mitchell (2003) says child literature embraces all genres including picture books, poetry, fairy tales, myths, traditional stories, information books, and so on. 
Basically, according to Surempaet in Fitriana's scientific work, children's literature and general literature are different based on the presentation of language, cognition, psychological, social stories. Therefore in determining the formula also comes different. Here the author tries to reformulate some of the differences between the two, as follows:

\section{1) Based on the Theme}

The theme presented can be the same but what distinguishes it was the theme of children's literature deliberately created to educate children. One of the examples was the theme of love. Children's love story was more to love to parents, love to brother and sister, love for the environment and love for animals. As for the story of love for the opposite sex just introducing them what it meant to love without the scenes above age. Unlike the case with adult literature, the theme of love that was presented tends to love the opposite sex that adults could watch. For example, like a love story in the movie Titanic.

\section{2) Based on the Language Presented}

In children's literature, the language presented was simpler and easier for children to understand because it returned again to the original goal of entertaining and educating. If the language was difficult to understand, they were not only difficult to understand the story but the message from the movie that was delivered couldn't be absorbed. Another language that was created in adult literature, usually tended to be complex and complex because adults have learned the language for a longer period of time and were certainly rich in vocabulary, especially those who had studied in higher education where the level of language used was high.

\section{3) Based on Imagination}

The imagination of children and adults was certainly different; therefore the imagination created in literary works is also different. Child literature tended to have a high imagination in order to build children's emotions while watching the movie, whereas adult literature of imagination was normal because most adults tended to be attracted to reality rather than imagination alone.

\section{4) Based on Social Stories}

Stories conveyed in children's literature were usually lighter social stories; included stories about friendship, family, school, playground, teacher, and so on. But in adult literature was more complex such as domestic violence, quarrels between the opposite sexes due to love, debate over a region, and so forth.

\section{5) Based on Audience Interest.}

The last difference was audience interest. Interest in children and adults was certainly different. Usually children tended to like things that didn't make sense, but there were already conventions in them such as stories of animals that could communicate with humans, cars that could move on their own and talked like humans and fairy stories from heavenly countries. While adults prefer stories that arouse a sense of romance between Romeo and Juliet or the story of the battle like The Hunger Game that tests the adrenaline of the audience.

Here were some similarities in the research samples that have been determined by researchers in Walt Disney Movie namely Tangled, Brave, and Frozen as listed in the following table: 
Figure 1. Similarities in the Research Samples

\begin{tabular}{|c|l|l|l|}
\hline \multirow{2}{*}{ No. } & \multicolumn{3}{|c|}{ Title } \\
\cline { 2 - 4 } & $\begin{array}{c}\text { Tangled } \\
(\mathbf{2 0 1 0})\end{array}$ & $\begin{array}{c}\text { Brave } \\
(\mathbf{2 0 1 2})\end{array}$ & \multicolumn{1}{|c|}{$\begin{array}{c}\text { Frozen } \\
(\mathbf{2 0 1 3})\end{array}$} \\
\hline 1 & $\begin{array}{l}\text { Palace, } \\
\text { forest }\end{array}$ & $\begin{array}{l}\text { Palace, } \\
\text { forest }\end{array}$ & $\begin{array}{l}\text { Palace, } \\
\text { forest }\end{array}$ \\
\hline 2 & Woman & Woman & Woman \\
\hline 3 & Princess & Princess & Princess \\
\hline 4 & Bravery & Bravery & Bravery \\
\hline 5 & Magic & Magic & Magic \\
\hline 6 & True Love & True Love & True Love \\
\hline 7 & Inlogic & Inlogic & Inlogic \\
\hline 8 & $\begin{array}{l}\text { Happy } \\
\text { ending }\end{array}$ & $\begin{array}{l}\text { Happy } \\
\text { ending }\end{array}$ & $\begin{array}{l}\text { Happy } \\
\text { ending }\end{array}$ \\
\hline
\end{tabular}

From some of the similarities above, then the researchers determine the formula that was in the genre of children's literature in Walt Disney Movie. The Formula of children literature in Walt Disney Movie was as follows:

\begin{tabular}{|c|c|c|c|}
\hline $\begin{array}{c}\text { Children } \\
\text { Literature } \\
\text { Formula } \\
\end{array}$ & $\begin{array}{l}\text { Tangled } \\
(2010)\end{array}$ & $\begin{array}{l}\text { Brave } \\
(2012)\end{array}$ & $\begin{array}{c}\text { Frozen } \\
(2013)\end{array}$ \\
\hline $\begin{array}{l}\text { The story } \\
\text { began with } \\
\text { happiness }\end{array}$ & $\begin{array}{l}\text { Queen } \\
\text { gave birth } \\
\text { to a baby } \\
\text { girl named } \\
\text { Rapunzel. }\end{array}$ & $\begin{array}{l}\text { King Fergus } \\
\text { and Queen } \\
\text { Elinor } \\
\text { played with } \\
\text { his daughter, } \\
\text { Merrida. }\end{array}$ & $\begin{array}{l}\text { Elsa and } \\
\text { Anna } \\
\text { played } \\
\text { snowballs } \\
\text { together. }\end{array}$ \\
\hline $\begin{array}{l}\text { The } \\
\text { occurrence } \\
\text { of an event } \\
\text { / disaster }\end{array}$ & $\begin{array}{l}\text { An old } \\
\text { woman } \\
\text { kidnapped } \\
\text { Rapunzel. }\end{array}$ & $\begin{array}{l}\text { Ratu Elinor } \\
\text { invited and } \\
\text { forced } \\
\text { Merida to } \\
\text { behave like } \\
\text { a royal } \\
\text { princess. } \\
\text { Queen } \\
\text { turned into a } \\
\text { big bear. }\end{array}$ & $\begin{array}{l}\text { Unintention } \\
\text { ally Elsa's } \\
\text { strength } \\
\text { caused } \\
\text { Anna to be } \\
\text { injured so } \\
\text { that her } \\
\text { hair was } \\
\text { white and } \\
\text { had to be } \\
\text { treated by } \\
\text { fairies. }\end{array}$ \\
\hline $\begin{array}{l}\text { Monotono } \\
\text { us space } \\
\text { setting }\end{array}$ & $\begin{array}{l}\text { Took the } \\
\text { setting of a } \\
\text { house in } \\
\text { the middle } \\
\text { of a forest } \\
\text { surrounded } \\
\text { by } \\
\text { waterfalls } \\
\text { and } \\
\text { mountains } \\
\text { that were } \\
\text { so } \\
\text { beautiful } \\
\text { cave and } \\
\text { Palace. }\end{array}$ & $\begin{array}{l}\text { Palace, } \\
\text { forest, small } \\
\text { hut. }\end{array}$ & $\begin{array}{l}\text { Palace, } \\
\text { Forest. }\end{array}$ \\
\hline $\begin{array}{l}\text { The main } \\
\text { character } \\
\text { was brave }\end{array}$ & $\begin{array}{l}\text { Palace, } \\
\text { Forest, } \\
\text { little hut. } \\
\text { Rapunzel }\end{array}$ & $\begin{array}{l}\text { Protect the } \\
\text { Bear } \\
\text { (Queen) } \\
\text { from the }\end{array}$ & $\begin{array}{l}\text { On the way } \\
\text { to find } \\
\text { Elsa, Anna } \\
\text { found }\end{array}$ \\
\hline
\end{tabular}

\begin{tabular}{|c|c|c|c|}
\hline & $\begin{array}{l}\text { dared to } \\
\text { leave the } \\
\text { house even } \\
\text { though the } \\
\text { old woman } \\
\text { always } \\
\text { forbade it } \\
\text { on the } \\
\text { grounds } \\
\text { that the } \\
\text { outside } \\
\text { world was } \\
\text { very cruel. }\end{array}$ & $\begin{array}{l}\text { soldier who } \\
\text { wanted to } \\
\text { kill him. } \\
\text { Dare to } \\
\text { follow the } \\
\text { light of } \\
\text { hope. }\end{array}$ & $\begin{array}{l}\text { many } \\
\text { obstacles } \\
\text { and } \\
\text { obstacles } \\
\text { but she was } \\
\text { never } \\
\text { afraid and } \\
\text { gave up. }\end{array}$ \\
\hline $\begin{array}{l}\text { There was } \\
\text { a song } \\
\text { while } \\
\text { doing } \\
\text { certain } \\
\text { work }\end{array}$ & $\begin{array}{l}\text { Rapunzel } \\
\text { sang while } \\
\text { cleaning } \\
\text { the house, } \\
\text { when she } \\
\text { first left } \\
\text { home, her } \\
\text { birthday. }\end{array}$ & - & $\begin{array}{l}\text { At the } \\
\text { beginning } \\
\text { of the } \\
\text { movie } \\
\text { when they } \\
\text { were } \\
\text { working } \\
\text { carrying } \\
\text { ice. When } \\
\text { Anna } \\
\text { invited Elsa } \\
\text { to play. } \\
\text { When the } \\
\text { gate is } \\
\text { opened } \\
\text { again. } \\
\text { When } \\
\text { Anna falls } \\
\text { in love with } \\
\text { Hans. } \\
\text { When Elsa } \\
\text { left the } \\
\text { palace. } \\
\text { When you } \\
\text { imagine, } \\
\text { you are in } \\
\text { the } \\
\text { summer. } \\
\text { When } \\
\text { Anna meets } \\
\text { Elsa in the } \\
\text { snow } \\
\text { palace, } \\
\text { when } \\
\text { Kristof } \\
\text { brings } \\
\text { Anna to the } \\
\text { fairy. }\end{array}$ \\
\hline $\begin{array}{l}\text { There was } \\
\text { always } \\
\text { magic }\end{array}$ & $\begin{array}{l}\text { Rapunzel's } \\
\text { hair and } \\
\text { singing. }\end{array}$ & $\begin{array}{l}\text { A magical } \\
\text { wizard's } \\
\text { cake made } \\
\text { the queen } \\
\text { turned into a } \\
\text { bear. Broom } \\
\text { could clean } \\
\text { the hut by } \\
\text { itself. }\end{array}$ & $\begin{array}{l}\text { Elsa's } \\
\text { magic can } \\
\text { freeze } \\
\text { anything } \\
\text { including } \\
\text { the world. }\end{array}$ \\
\hline $\begin{array}{l}\text { Animals } \\
\text { can } \\
\text { understand } \\
\text { humans }\end{array}$ & $\begin{array}{l}\text { Toad, } \\
\text { horse, } \\
\text { rabbit. }\end{array}$ & $\begin{array}{l}\text { Crow. } \\
\text { Horse. }\end{array}$ & Horse \\
\hline
\end{tabular}




\begin{tabular}{|c|c|c|c|}
\hline $\begin{array}{l}\text { The } \\
\text { presence } \\
\text { of helpers }\end{array}$ & $\begin{array}{l}\text { A thief } \\
\text { named } \\
\text { Flynn. }\end{array}$ & Witch. & $\begin{array}{l}\text { Fairy. } \\
\text { Kristof. } \\
\text { Olaf }\end{array}$ \\
\hline Adventure & $\begin{array}{l}\text { Rapunzel } \\
\text { and Flynn } \\
\text { fight the } \\
\text { royal } \\
\text { forces, } \\
\text { they are } \\
\text { trapped in } \\
\text { a cave. }\end{array}$ & $\begin{array}{l}\text { Bears } \\
\text { (Queen) and } \\
\text { Merrida } \\
\text { look for } \\
\text { back } \\
\text { witches. } \\
\text { Living } \\
\text { together in } \\
\text { the forest. } \\
\text { Archery of } \\
\text { fish to eat. }\end{array}$ & $\begin{array}{l}\text { Take a long } \\
\text { journey in } \\
\text { Elsa's } \\
\text { search. }\end{array}$ \\
\hline Sacrifice & $\begin{array}{l}\text { Rapunzel } \\
\text { sacrificed } \\
\text { herself so } \\
\text { that Flynn } \\
\text { was } \\
\text { released. }\end{array}$ & $\begin{array}{l}\text { Maintain } \\
\text { and care for } \\
\text { queens } \\
\text { while living } \\
\text { in the forest. }\end{array}$ & $\begin{array}{l}\text { Elsa } \\
\text { steered } \\
\text { clear of } \\
\text { Anna so as } \\
\text { not to hurt } \\
\text { her, even } \\
\text { though Elsa } \\
\text { misses her } \\
\text { time } \\
\text { together. } \\
\text { Anna hold } \\
\text { back the } \\
\text { sword Hans } \\
\text { sent to } \\
\text { Elsa. }\end{array}$ \\
\hline True love & $\begin{array}{l}\text { True love } \\
\text { of } \\
\text { Rapunzel } \\
\text { dan Flynn. }\end{array}$ & $\begin{array}{l}\text { True love } \\
\text { Merrida } \\
\text { with the } \\
\text { queen so } \\
\text { that her tears } \\
\text { could turn } \\
\text { the queen } \\
\text { back into a } \\
\text { human. }\end{array}$ & $\begin{array}{l}\text { Elsa's love } \\
\text { for Anna, } \\
\text { with her } \\
\text { tears Anna } \\
\text { recovered } \\
\text { from magic } \\
\text { that hurt } \\
\text { her. }\end{array}$ \\
\hline $\begin{array}{l}\text { Happy } \\
\text { ending }\end{array}$ & $\begin{array}{l}\text { Rapunzel } \\
\text { returned to } \\
\text { the Queen } \\
\text { and King } \\
\text { to the } \\
\text { Palace. }\end{array}$ & $\begin{array}{l}\text { They } \\
\text { returned to } \\
\text { the palace } \\
\text { and lived as } \\
\text { normal, but } \\
\text { now the } \\
\text { queen and } \\
\text { Merrida got } \\
\text { closer. }\end{array}$ & $\begin{array}{l}\text { Elsa } \\
\text { becomes } \\
\text { queen } \\
\text { again and } \\
\text { Anna is } \\
\text { dating } \\
\text { Kristof. }\end{array}$ \\
\hline
\end{tabular}

Walt Disney Movie formulas as listed above could change at any time, adjusted to the tastes and demands of the community. The formula of child literature was a little bit boring and the ending was predictable. As described in the table above, the beginning of the story always started with happiness which from the happiness then raised the problem so that it destroyed the happiness at the beginning of the story. Here, children were asked to think hard about how to solve the problem even though the producer has arranged it in such a way, but they still have their own ways of solving the problem. Enhence, it was not uncommon for them to be angry or even upset when watching because of their dissatisfaction with the producer in solving the problems in the movie scene. While the audience showed such response, the producer had succeeded in making the movie interesting and even popular.

The setting of the place used was mostly natural. Children tended to like the outdoors which represented freedom in the way they think. Basically, children were happy with something foreign and beyond the reality of life like the setting in the Tangledmoviewas a tall tower surrounded by trees, mountains and waterfalls, it looked so beautiful even though they knew it's not real. Returning to the audience's request, the setting as mentioned above was also a request or adjusted to what the children like so that the setting becomes important to be included in the children's literary formula.

In the formula table above also mentioned courage, sacrifice, adventurer, and true love. Why was this important? First, went back to the original goal of entertaining and educating. In children's literature intentionally created characters such as brave, sacrificial, and adventurous so that they can imitate these characters in everyday life because children tend to imitate what they see. Secondly, the true love offered by child literature in Walt Disney Movie tended to not be abandoned because it was also something that attracts the attention of the audience. As in the Brave and Frozen stories, true love was the one that solves the problem of the conflict in the story so that it became important.

Then there was a magic. Why was magic important so that it entered the formula? Agains 
the author have to say according to what was loved by children. Magis was one think that interected the children because with the magic something that couldn't happened, could be happened. It tended to be illogical when viewed from the real-life perspective. For example, only a cake can turn Merrida's mother into a giant bear. In real life it is impossible to happen, but even so the audience can accept the convention so they really enjoy the situation.

Happy ending, that's the ending that was usually offered by Walt Disney Movie because kids tended to like happy ending compared to sad ending. If presented with sad ending children will quickly feel bored and not interested. Children were synonymous with fun and joy, with that producing the movie must create an ending that can make children happy.Those were some factors why the formula table above could be formed. Why could it be popular? Almost all Walt Disney Movie were popular because the movies offered were always based on the demands and expectations of the community. If people were being started to get bored with one formula then they will form a new formula to attract the audience again, usually it happens as the period changes.

Children's literature in Walt Disney Movie was certainly different from children's literature in other movie productions. For example, Warner Bros Picture, this movie studio creates more children's literature in the form of families' stories such as Orphan, Funky Monkey, Mysterious Island, and Dolphin Tale 2. Walt Disney Movie tended to focus on the fantasy sub genre. Each movie studio has its own superior program and kept trying to improve itself as time goes by, of course, adjusted to market consumption so that the movie studio is no less competitive.

\section{CONCLUSION}

Children's literature and adult literature have different characters; Child literature tended to tell about the lives of children whose purpose was not only to entertain but also to educate. While adult literature or literature generally talked about daily events but was more complicated than the stories of children because the intelligence they have were different from children. However, both can be investigated using a formula approach.

The formation of the child literature formula in Walt Disney Movie was based on several things, namely the theme, characterization, storyline, and setting of the place. This formula was formed also because of the audience's interests and expectations, so that the formula could change at any time in accordance with the tastes of the people who enjoyed it and not be surprised if it could instantly be popular. That was caused by the intelligence of the producer in determining the direction of production so that the people really felt to be satisfied.

\section{REFERENCES}

Adi Rochani, I. (2011). Fiksi Populer: Teori dan Metode Kajian. Yogyakarta: Pustaka Pelajar.

Adi, I. R. (2014). Serial televisi Dexter sebagai anakronisme dalam sastra populer. LITERA, 13(1). Retrieved from http://journal.uny.ac.id/index.php/litera/artic le/view/1881

Cawelty, J. G. (1976). Adventure, Mystery, and Romance. Chicago: University of Chicago Press.

Endraswara, S. (2011). Metodologi Penelitian Sastra. Yogyakarta: Pustaka Pelajar.

Huck's, C. (2010). Children's Literature. New York: Mc Graw Mill.

Lukens, R. J. (2013). A Critical Handbook of Children's Literature. New York: United State of America Printed. 
Mitchell, D. (2003). Children's Literature: An Invitation to the World. New York: Allyn and Baron.

Mulhern, C. (1999). Japanese Harlequin Romances as Transcultural Woman's Fiction. The Journal of Asian Studies, 48(1), 50-70. Retrieved from doi:10.2307/2057664

Nurgiyantoro, B. (2004). Sastra Anak: Persoalan Genre. Humaniora, 16(02). Retrieved from https://journal.ugm.ac.id/index.php/jurnalhumaniora/article/view/811

Swirski, P. (1999). Popular and Highbrow Literature: A Comparative View. Purdue University Press, 1(4), 36-46. Retrieved from http://docs.lib.purdue.edu/clcweb/vol1/iss4/ 4 